\title{
エチレンービニルアルコール共重合体の分子間ホルマール化速度に 対するポリマー濃度の影響
}

\author{
米津 潔*1
}

（受付 1993 年 2 月 5 日・蕃査終了1 1993 年 2 月 25 日）

\begin{abstract}
要 旨 エチレンービニルアルコール共重合体 (EVOH) をジチルスルホキシド/水系溶媒中でホルマール化し， Charlesby のゲル化理論を適用して分子間ホルマール化速度を解析し以下の結果を得た。 (1) ゲル化点までの速度 は, EVOH 湌度 $([\mathrm{OH}])$ の低い領域では $[\mathrm{OH}]$ のはぼ 1 次に比例して增加するが，[OH] $=0.6 \mathrm{~mol} / /$ 以上ではその 依存性が変化し著しく增加する。この传存性が大きく变化する点は，ポリマ一鎖のからみ合いを生じ始める浱度に 対応している. (2) ゲル化点以後のポリマー1 分子当たりの架橋生成速度は架橋指数にほぼ比例し, [OH] が低いほ ど大きい，これは，ゲル化点以後ミクロゲルを中心に架橋が生成し，[OH]かか高くなるほどミクロゲルへのポリ マーの㹡散が遅くなり，架橋の生成が㧕制されることを示唆している。
\end{abstract}

\section{1 楮 言}

著者はすでに，エチレンービニルアルコール共重合体 (EVOH) のジメチルスルホキシド (DMSO) を主溶媒と する均一溶液でのアセタール化を行い, 分子間アセター ル化反応が起こることを推定した1)。ポリビニルアル コール (PVA) の水溶液中でのアセタール化において, 分子間アセタール化反応が起こることは，すでに認めら れている. 桜田らは，末端にアルデヒド基をすつ過ヨウ 素酸分解 PVA の酸性水溶液中で分子間アセタール化を 検討し，この反応が PVA 濃度の影響を大きく受けるこ とを認めている2． 松沢は上記の分子間アセタール化に おいて, 分子量上昇の統計的計算を行い, 実験結果と比 較している 化を均一系之不均一系で行い, 各々の酢化物の溶解性加 ら不均一系のホルマール化において橋かけが生ずると結 論し、この橋かけがホルムアルデヒド濃度, 酸濃度が高 いほど起こりやすいことを認め, トリオキシメチレング リコールによる橋かけが存在すると推定している゙), 5). また，川瀬は PVA 水溶液のアセトアルデヒドによるア セタール化において, アセタール化度が同じでも均一系 と不均一系では各々ジオキサンによる溶解性が異なり, 不均一系で橋かけが起こると結論している6゙?. しかし， これらの研究においては, 分子間アセタール化の速度論 的研究はあまりなされていない，また，EVOH の分子間 アセタール化についての研究は, 全く見あたらない。

分子間アセタール化によるポリマー架橋の生成におい $\tau, \mathrm{EVOH}$ の OH 基が分子の大きさや分子内の位置に全

*1 高知工業高等専門学校（７83 南国市物部乙 200-1）
く無関係, 無秩序に反応し架橋が形成されるものとすれ ば, Charlesby の理論早が適用できると考えられる. Charlesby の理論によれば，ポリマーが架橋して溶媒に 不溶性のゲルを生成しはじめる点であるゲル化点の条件 は, ポリマー 1 分子当たりの平均架橋点の数が, 数平均 重合度と重量平均重合度の比になる。

著者は, EVOH のホルムアルデヒドによるアセタール 化 (FA 化)に上記理論を適用し,ゲル化点の測定から分 子間 FA 化反応速度を求めることを試みた。その結果, ゲル化点に達するまでの反応速度がポリマー濃度に大き く依存し，それがポリマーの溶液状態に起因することを 明らかにした。 また, 上記理論からゲル化点以後の分子 間反応についても解析し，予想外にもポリマー濃度の低 い方か架橋速度が速いことを認めた。本報では，これら の点について報告する.

\section{2 実跧方法}

\section{1 試薬}

EVOH は(株)クラレより提供されたものを用いた。 エ チレン含有率は $32 \mathrm{~mol} \%$, 数平均重合度 $\left(P_{n}\right)$ は 540 , 重 量平均重合度 $\left(P_{w}\right)$ は 1080 である. DMSO, メチルアル コール，ホルマリン，浱塩酸はいずれも試薬特級をその まま用いた。 ホルマリンはホルムアルデヒド 37\%,メチ ルアルコール10\% 含有水溶液である.

\subsection{FA 化反店}

試料 EVOHをDMSO に溶解してホルマリンを添加し た後, 塩酸 $(\mathrm{HCl})$ を触媒として加え $60^{\circ} \mathrm{C}$ で反応させた. 反応系の $\mathrm{EVOH}$ 濃度は $\mathrm{OH}$ 基当たり $0.24 \sim 1.02 \mathrm{~mol} / \mathrm{l}$, $\mathrm{DMSO} / \mathrm{H}_{2} \mathrm{O}$ 組成は $\mathrm{H}_{2} \mathrm{O} 10 \%, \mathrm{HCl}$ 濃度は $0.13 \mathrm{~mol} / \mathrm{l}$, $\mathrm{EVOH}$ の OH 基に対するアルデヒドのモル比を 2〜9 
し，反応中は終始十分に混合した，反応後，反応液を大 量の水中に加えてポリマーを析出させ, 水で十分に洗浄 した後 $105^{\circ} \mathrm{C}$ で 6 時間乾燥させ分析に供した.

\section{3 測定}

反応後ポリマーのゲル分率の測定は, DMSO が FA 化 EVOH の良溶媒であることから，以下のように行った。 試料 $w_{1} \mathrm{~g}$ に DMSO $50 \mathrm{~m} l$ を加え, $60^{\circ} \mathrm{C}$ で 6 時間混合溶 解した後遠心分離して上澄み液を除去し，不溶解分を DMSO で洗浄後メチルアルコールに浸せきし，減圧滤 過後乾燥して不溶解分の重量 $w_{2} \mathrm{~g}$ を求め, $w_{2} / w_{1}$ をゲル 分率とした。

ポリマー溶液の粘度は, オストワルド型粘度計を用い $60^{\circ} \mathrm{C}$ で測定した.

FA 化度の測定は，試料を $35 \%$ 硫酸水溶液で分解し水 蒸気蒸留して行ういわゆる亜硫酸水素ナトリウム法")に 準拠して行った.

\section{3 実畭結果およひ考案}

\section{1 ゲル化点までの分子間 FA 化反応}

EVOH 港度 $0.47 \mathrm{~mol} / l$, 温度 $60^{\circ} \mathrm{C}$ において FA 化反 応を行い, 反応時間とポリマーのゲル分率 $(g)$ の関係を 求め, 結果を Fig. 1 に示した. Fig. 1 より gが0となる 時間を外挿して求め, これをゲル化点に達する時間 $\left(t_{8}\right)$ と定めた。

各 EVOH 浱度において $t_{\mathrm{g}}$ を求め, この関係を Fig. 2 に示した. $t_{\mathrm{s}}$ は EVOH 浱度が $0.6 \mathrm{~mol} / l$ ぐらいまではゆ るやかに低下するが，それ以後急激に低下する，その前 後の EVOH 浱度で反応系の状態は大きく異なる．すな わち約 $0.6 \mathrm{~mol} / l$ 以下では, ゲル化点に達した頃から系 は白濁しだし，徐々に白濁が激しくなっていく，一方， これより高い EVOH 浱度では，ゲル化点に達した頃か ら系は透明なまま粘度が急上昇し，その後透明なゲルに

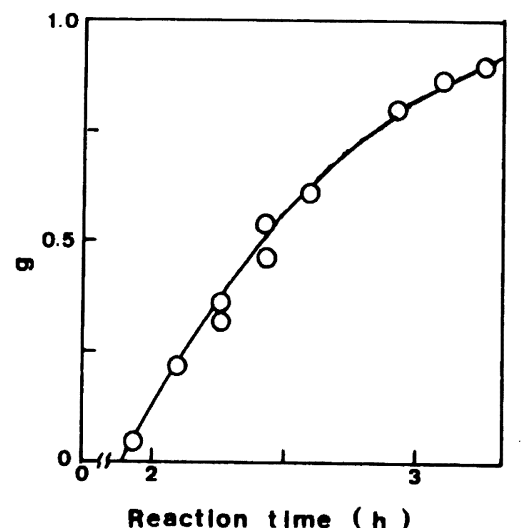

Fig. 1. Relation between gel fraction $(g)$ and reaction time. Concentration of $\mathrm{EVOH}=0.47 \mathrm{~mol} / \mathrm{l}$.
成長する。

Charlesby の理論より,ゲル化点におけるポリマー鎖 1 個当たりの平均架橋点の数 $\left(\gamma_{c}\right)$ は $P_{n} / P_{w}$ で示される. し たがって， $t_{\mathrm{g}}$ の逆数はポリマー鎖 1 個当たりの架橋速度 を表し, EVOH 濃度との積 $[\mathrm{OH}] / t_{\mathrm{g}}$ は系の分子間 FA 化 反応速度に比例した值を示すことになる。

$[\mathrm{OH}] / t_{\mathrm{g}}\left(\mathrm{mol} \Gamma^{-1} \mathrm{~min}^{-1}\right)$ の [OH] への依存性を Fig. 3

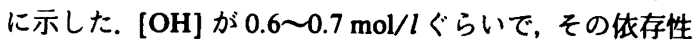
は大きく変化している.これは, 前述したゲル化点以後 における系の状態変化の差と明らかに対応していると思 われる. Fig. 3 より， $[\mathrm{OH}]$ が $0.6 \mathrm{~mol} / \mathrm{l}$ 以下の希薄溶液 では, $[\mathrm{OH}] / t_{\text {子は }}[\mathrm{OH}]$ のほぼ 1 次に比例しており，そ れより濃厚な溶液では，実験した範囲においてほぼ 5 次 に比例していることがわかる.この原因はポリマーの溶 液状態によるあのと考えられ，次節で考察する.

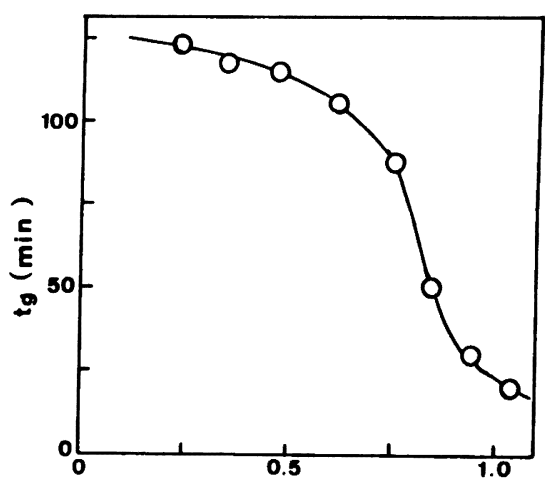

[OH] $(\mathrm{mol} / \mathrm{l})$

Fig. 2. Relation between gelation time $\left(t_{\varepsilon}\right)$ and concentration of EVOH ([OH]).

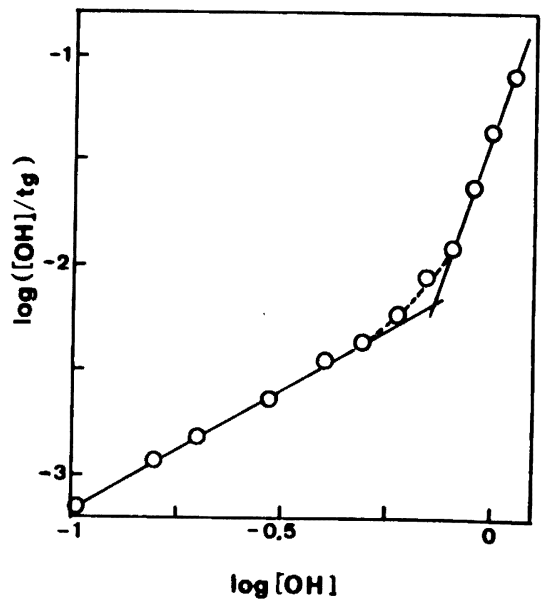

Fig. 3. Doubly logarithmic plot of $[\mathrm{OH}] / t_{\mathrm{g}}$ vs. $[\mathrm{OH}]$ 


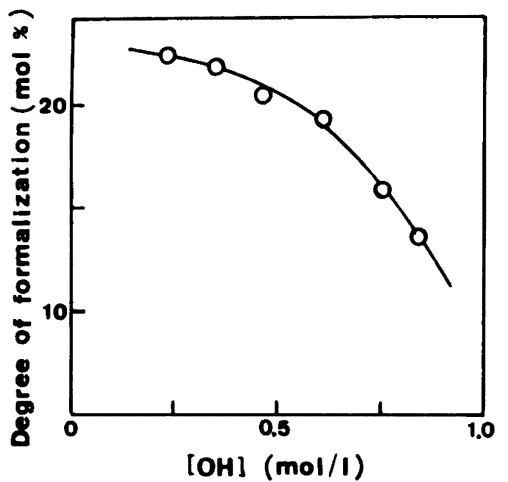

Fig. 4. Relation between the degree of formalization at gel point and $[\mathrm{OH}]$.

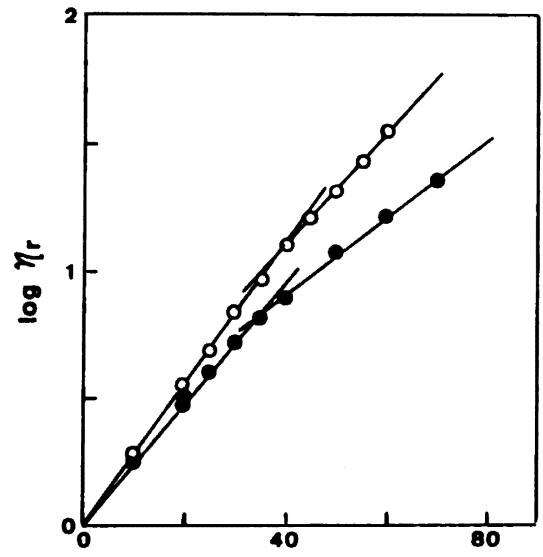

Polymer concentration $(g / \mathrm{I})$

Fig. 5. Dependence of relative viscosity $\left(\eta_{r}\right)$ on concentration of polymers at $60^{\circ} \mathrm{C}$ in DMSO/ $\mathrm{H}_{2} \mathrm{O}$ mixture (9/1 wt.). (O), EVOH; (O), formalized EVOH (degree of formalization $=17.4 \mathrm{~mol} \%$ ).

ゲル化点における分子内および分子間トータルの FA 化度と [OH] の関係を Fig. 4 に示した. [OH] が低いほ ど FA 化度が高いが，これは [OH] が低いほど $t_{\mathrm{g}}$ が大き いことから当然分子内 FA 化がより進行しているためで ある. EVOH の $\gamma_{c}=1 / 2$ より, 分子間 FA 化と分子内 FA 化の速度比を概算すると $6 \times 10^{-3} \sim 1.4 \times 10^{-2}$ となる.

\section{2 ポリマーの DMSO $/ \mathrm{H}_{2} \mathrm{O}$ 系溶液の粘度}

反応系におけるポリマーの溶液状態を明らかにするた め, 反応系に近い条件, すなわち $\mathrm{DMSO} / \mathrm{H}_{2} \mathrm{O}=9 / 1$ (wt 比), 温度 $60^{\circ} \mathrm{C}$ で EVOH および FA 化物（FA 化度 17.4 mol\%) の DMSO/ $\mathrm{H}_{2} \mathrm{O}$ 系溶液粘度を测定した. Fig. 5 に ポリマー涱度と溶液相対粘度の対数の関係を示した.こ の結果, 両者はほぼ直線関係を示し，ポリマー浱度が 35 $\sim 40 \mathrm{~g} / l$ で折れ曲がることを示している. この点につい て, 内藤らはPVA の水溶液の粘度を詳細に調へ，直線 の折れ曲がるポリマー濃度において，ポリマーのからみ

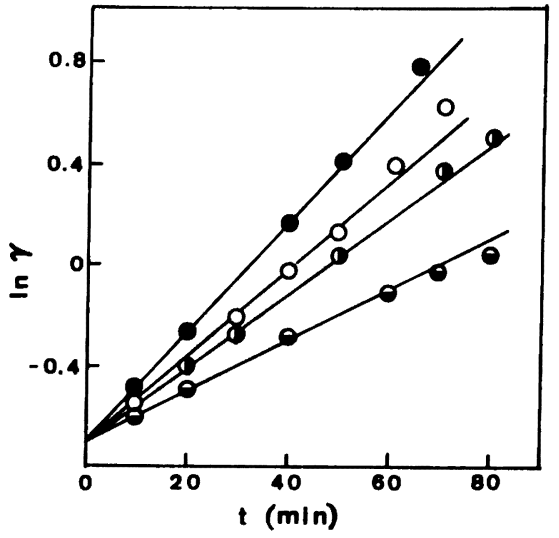

Fig. 6. Dependence of crosslinking index $(\gamma)$ on reaction time after gel point $(t) .[\mathrm{OH}](\mathrm{mol} / \mathrm{l}):(O)$, 0.24; (O), 0.47; (O), 0.76; (Ө), 0.94 .

合いが生じ始める点であると論じている ${ }^{10}$.

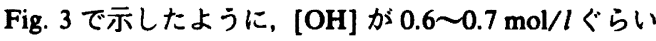
で $[\mathrm{OH}] / t_{\mathrm{g}}$ の $[\mathrm{OH}]$ への依存性が大きく变化するが, こ れをポリマー濃度に換算すると $34 \sim 40 \mathrm{~g} / l$ となる：この 浱度は Fig. 5 の結果より, 反応系においてポリマーがか らみ合いを生じ始める点と良く一致している。

この結果から，ゲル化点までの分子間 FA 化反応の機 構は, 定性的に次のように説明される. [OH] $0.6 \mathrm{~mol} / l$ 以下では，ポリマーは溶液中で孤立した状態にあり，分 子間反応が起こるためには溶媒和したポリマー同士が接 近し接触することが必要になる。この時, 一方のポリ マーの OH 基がへミアセタール化され，そこへ他方のポ リマーの OH 基が接触して FA 化が起こることになる. 反応速度が $[\mathrm{OH}]$ のほぼ 1 次に比例していることは, OH 基のへミアセタール化か， あるいは他方のポリマー の OH 基のへミアセタール部への接触のいずれかが反 応律速になっていることを示している. 分子内アセター ル化においては, へミアセタールの生成段階が律速であ るといわれており"1)，本実験では，前節に示したように 分子間反応が分子内反応より著しく遅いことから，ポリ マー同士の衝突が律速になっていることを容易に推察で きる.

一方, [OH] $0.6 \mathrm{~mol} / l$ 以上では溶液中においてポリ マー鎖の接触，あるいはからみ合いを生じるいわゆる準 濃厚溶液の系になっており，3 次元的な接触のため，反 応速度が $[\mathrm{OH}]$ の高次に依存するするすのと考えられ る. 奏験した簕囲にいおて，[OH] のほぼ 5 次に比例し ているが，この点について明解に論ずることはできな い.

\section{3 ゲル化点以後の分子间 FA 化反応}

Charlesby の理論によれば，無秩序分布のポリマーに 
おけるゲル分率 $(g)$ と、ポリマー 1 分子当たりの平均架 橋点数 $(\gamma)$ の間には式 (1) の関係がある ${ }^{8)}$.

$$
g=1-\frac{1}{\left(1+\gamma_{g}\right)^{2}}
$$

したがって，ゲル分率の測定よりゲル化点以後の架橋 点数の経時変化，すなわち，分子間 FA 化反応速度を求 めることができる. ただし，この場合ゲル分とソル分の 間でエチレン含有率の差はないと仮定する. 式 (1) より 各ポリマー嶩度における $\gamma$ の経時変化を求め, Fig. 6 に ゲル化点に達した以降の反応時間 $(t)$ と $\gamma$ の対数の関係 を示した。この結果， $\mathrm{g}$ があまり高くない範囲において 両者はほぼ直線関係があり, $t$ と $\gamma$ は式 (2) の関係で示 される.

$$
\frac{\mathrm{d} \gamma}{\mathrm{d} t}=k r
$$

ここで $\boldsymbol{k}$ は定数で, Fig. 6 の直線の勾配に相当する. $k$ 値 が、ポリマー浱度が高いほど小さくなっていることは興 味深い.

これらの結果より,ゲル化点以後の分子間ホルマール 化による架橋生成について, 定性的に次のように推察さ れる. ゲル化の初期において, 溶液が白濁あるいは粘度 上昇することより、いわゆるミクロゲルが系内に多数生 成すると思われる. $\gamma$ はミクルゲルの数に比例すると考 えれば, 式 (2) は架橋の生成速度がミクロゲルの数に比 例することを示し、 ミクロゲルを中心に架橋が成長して いくことを示唆している. この時, ポリマー浱度の高い 方がゲル化点に早く達し, 当然ミクロゲルの数が多いと 考えられるにもかかわらず, $\gamma$ の経時変化，すなわち架 橋生成速度が小い，これは, ポリマー荟度が高いとミ
クロゲルへのポリマーの拡散速度が遅くなり, 架橋の生 成が抑制されるためと推定される.

\section{4 結語}

EVOH のホルマール化反応について, Charlesby の理 論をもとに整理し，分子間反応の起こることが明らかに なった. ‘た，架橋生成機構を考察するうえで，二，三 の興味ある結果が得られたが,これらを明解に議論する ため今後さらに実験が必要である.

期 辞 本研究に際し, EVOH 試料の提供, ならびに各種の 御援助を頂いた(株)クラレ開発センター青山明正氏に深く感謝 いたします。

\section{文献}

1) 米津 楔，高分子論文集，49, 993 (1992).

2) 桜田一郎, 松沢秀二, 高分子化学, 16, 90 (1959).

3) 松沢秀二，高分子化学，16,550 (1959).

4) 松沢秀二，井本友三久，岡崎正樹，高分子化学，25，25 (1968).

5）松沢秀二，井本友三久，小笠原健二，高分子化学，25，173 (1968).

6) 川激﨏二, 工業化学雑誌，74，1228 (1971).

7) 川桷㭲二, 工業化学雑誌, 74, 1458 (1971).

8) A. Charlesby, Proc. R. Soc., Ser. A, 222, 542 (1954).

9）桜田一郎，祖父江 䙾，久志宗茂編，“合成䄉維”，朝倉㫪 店, 東京 (1964), p. 214

10）内藤龍之介，浮田純二，小南次夫，高分子化学， 14，117 (1957).

11) Y. Ogata, M. Okano, and T. Ganke, J. Am. Chem. Soc., 78, 2962 (1956).

Effect of Polymer Concentration on the Rate of Intermolecular Formalization of Ethylene-Vinyl Alcohol Copolymer Kiyoshi YoNEzu*1

*1 Department of Industrial Chemistry, Kochi National College of Technology (200-1, Otsu, Monobe, Nankoku-shi, Kochi, 783 Japan)

Intermolecular formalization of ethylene-vinyl alcohol (EVOH) was studied kinetically in a dimethyl sulfoxidewater mixture on the basis of Charlesby's theory related to gelation of polymer. The effects of the concentration of EVOH ([OH]) on the rate were as follows. (1) The rate till the gel point was nearly proportional to [OH] at a concentration below $0.6 \mathrm{~mol} / l$, but above $0.6 \mathrm{~mol} / l$ the dependence of $[\mathrm{OH}]$ varied sharply and the rate increased remarkably. The change of the dependence was caused by the formation of polymer entanglement. (2) The rate of crosslinking a molecule after the gel point was approximately proportional to the crosslinking index and decreased with an increase in $[\mathrm{OH}]$. It was supposed that crosslinking occurred mainly in microgels, and the diffusion rate of the polymer into microgels decreased with an increase in $[\mathrm{OH}]$, and then the depression of the crosslinking formation followed.

KEY WORDS Ethylene-Vinyl Alcohol Copolymer / Formalization / Intermolecular Formalization / Charlesby's Theory / Kinetics / Gel Point /

(Received February 5, 1993: Accepted February 25, 1993)

[Kobunshi Ronbunshu, 50(8), 637-640 (1993)] 